\title{
HIP 複合シリンダーの耐食・耐摩耗性
}

\section{1.はじめに}

射出成形・押出成形技術の向上にともなって，パソコ ン・携帯端末等の OA 機器, 自動車, 家電製品, 精密機 械分野などに，各種のエンジニアリングプラスチック（以 下，エンプラと略す）の用途が拡大してきている.

このような状況のなかで，エンプラに対する要求特性は 多岐に渡り, 成形性の改善, ポリマー自体の改良, 添加剂 · 充填材の改善などの手法により, 新規グレードの種々エン プラの開発が盛んに行われ，上市されている.

これらのエンプラにはガラス綫維 (Glass Fiber, 以下 $\mathrm{GF}$ と略す）などの強化材や炭酸カルシウムなどの増量剤 が添加される場合が多く，最近では耐熱性向上のため上記 充填材が $40 \sim 50 \%$ 以上添加されてきている.ささらに，工 ンプラ製品の使用環境に応じて，ポリマー自体の難燃性を 高めたり，あるいは難燃剤などを添加することにより，樹 脂溶融時にハロゲン系の強腐食性分解ガスが発生する.

これらの影響により，エンプラおよび充填材が多量に添 加された沉用プラスチックの射出および押出成形に用いら れるシリンダーは, 摩耗と腐食による損耗が従来に比べて ますます激しくなってきている．このため，これらのプラ スチックの成形に対しては, 窒化鋼製シリンダーでは耐食 性と耐摩耗性の観点から対応できず，内面に $\mathrm{Ni}$ 基あるい は Co 基合金をライニングしたバイメタリック構造のシリ ンダーを使用することが一般的になっている.

バイメタリックシリンダーを製造方法で大別すると次の ように分類される.

(1)HIP 接合による方法

(2)遠心鋳造による方法

(3)その他（粉末治金法等）

また，材質的に見ると，以下のようになる.

(1) $\mathrm{Ni}$ 基合金あるいは $\mathrm{Ni}$ 基合金に硬質粒子添加

(2) Co 基合金あるいは Co 基合金に硬質粒子添加

(3) $\mathrm{Fe}$ 基合金に硬質相を分散

さらに近年，成形のハイサイクル化や薄肉製品の成形の ため, 高速・高圧射出成形が増えてきており, シリンダー に対して従来よりも高い耐圧強度が要求されるようになっ てきている.

本稿では, HIP 接合法によるバイメタリック構造のシリ

\footnotetext{
* Hada, Shinsuke/Minamide, Toshiyuki (侏神戸製鋼所 鋳鍛鋼事業部 粉末製品センター 高砂市荒井町新浜 2-3-1（解 $676-8670 ）$ 2001.12.27 受理
}

羽田晋 介**南 出 俊 幸* ンダー（以下，HIP 複合シリンダーと略す）の耐食・耐摩 耗性について紹介する.

\section{HIP 複合シリンダーの製造法と特徵}

ライニング層に粉末合金を用いる HIP 複合シリンダー の製造工程を図 1 に示す。

ライニング粉末は高温 $\left(900 \sim 1,000^{\circ} \mathrm{C}\right)$ ，かつ高圧 $(1,000$ $\mathrm{kgf} / \mathrm{cm}^{2}$ 前後）の HIP 処理条件下で，加圧焼結すると同 時に本体母材に固相にて拡散接合され，シリンダー内孔面 に2 $5 \mathrm{~mm}$ 厚さの緻密なライニング層が形成される。こ の HIP 接合法は, 従来のバイメタリック構造シリンダー の製造法として一般的となっている遠心鋳造法と比べて， 以下の特徵を有している.

1）ライニング合金は粉末のため成分設計の自由度が高く, 要求特性に合せて高合金化が可能である。 また，メカ ニカルアロイング法(以下，MA 法と略す)を採用 ${ }^{1)}$ し, 各種セラミックスとの複合化・分散強化も容易である.

2) ライニング層は微細かつ均一なミクロ組織となるので, 優れた耐食・耐摩耗性と高強度・高勒性を有している. 3 ） ライニング層と本体母材の間では強固な接合が形成さ れ，欠陥のない健全な接合部が得られる.

4 ） ライニング層の品質が製品サイズの影響を受けにくい プロセスであるので, シリンダーの品質が安定し, 再 現性も高い。

5 ) Near-Net Shape ライニングが可能で，シリンダーの 先端面やホッパ穴へのライニングが可能である.

\section{3. シリンダー用ライニング合金}

従来の窒化鋼製シリンダーでは，成形樹脂ごとにその耐 食性あるいは耐摩耗性を考虑した材質の選択の範囲が限ら れているが，バイメタリック構造のシリンダーでは，成形 樹脂ごとに適正ライニング合金にて対応できるメリットを 有している。このため, 成形樹脂・成形条件等に応じたラ イニング合金の使い分けが主流となっており，そのライニ ング合金はシリンダー製造メーカーのオリジナル合金が用 いられ，種々のライニング合金が開発され，提供されてい る) $^{2) 5}$.

最も多く使用されるのは $\mathrm{Ni}$ 基合金で，窒化鋼にない優 れた耐食性を有して打り，用途に応じて $\mathrm{Cr} ， \mathrm{Mo}$ 等の合 金元素を添加し，成分設計している．また，母地合金それ 自体ではさほど耐摩耗性を有していないため， B， Si を添 加し，ホウ化物，ケイ化物を析出させることにより耐摩耗 性を著しく向上させている場合が多い，特に耐摩耗性を重 
視する場合は, $\mathrm{VC}, \mathrm{WC}$ 等の炭化物を添加し, 分散強化 を図っている.

表 1 に高耐食・耐摩耗性が要求されるシリンダーのライ ニング合金として良く用いられている $\mathrm{Ni}$ 基の HIP 複合シ リンダーライニング合金を示す.

\section{4. シリンダーの腐食・摩耗形態}

シリンダーの摩耗が生じ易い部位は，一般的に樹脂供給
部と射出先端側チェックリングとの摺動部の 2 箇所である. 樹脂供給部は，樹脂ペレットが溶融し始める部位で，樹 脂中の $\mathrm{GF}$ 等の強化材がペレットから一部頭を出した状態 で，スクリュ回転によりシリンダー内面を摩耗させる。

この部位は，樹脂から発生する腐食ガスの影響をほとんど 受けない単純なアブレッシブ摩耗が支配的である.

一方，射出先端側は，樹脂が完全に溶融し，腐食性ガス による腐食と強化材およびチェックリングとの接触による
ライニング用粉末の製造
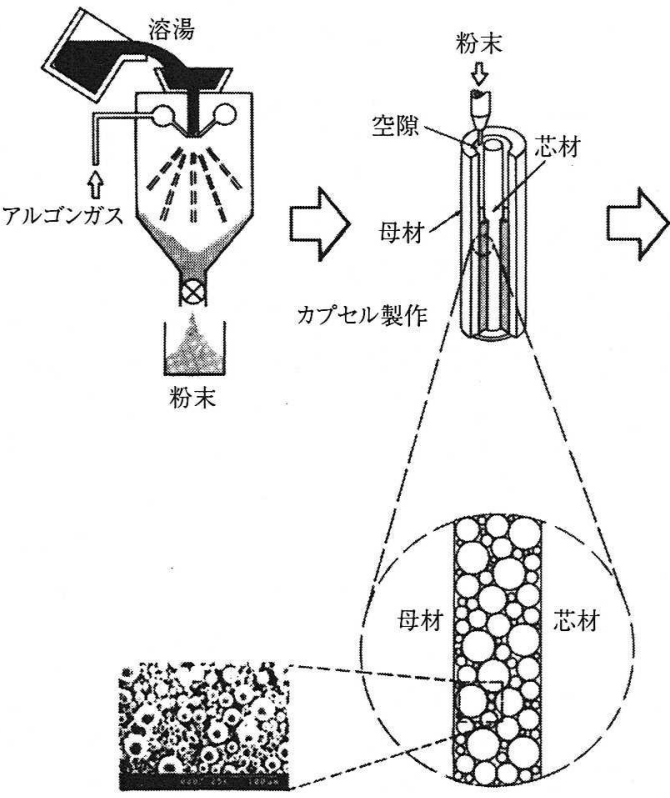

粉末充填後の状態

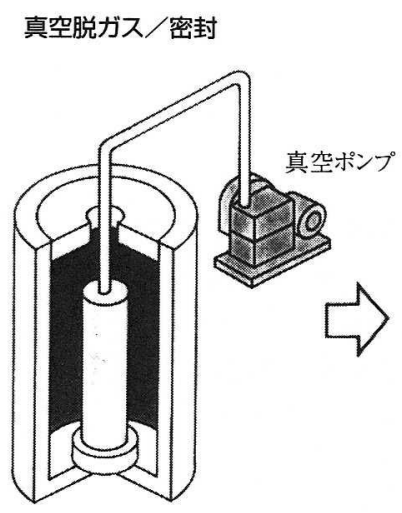

HIP処理

芯材除去／機械加工
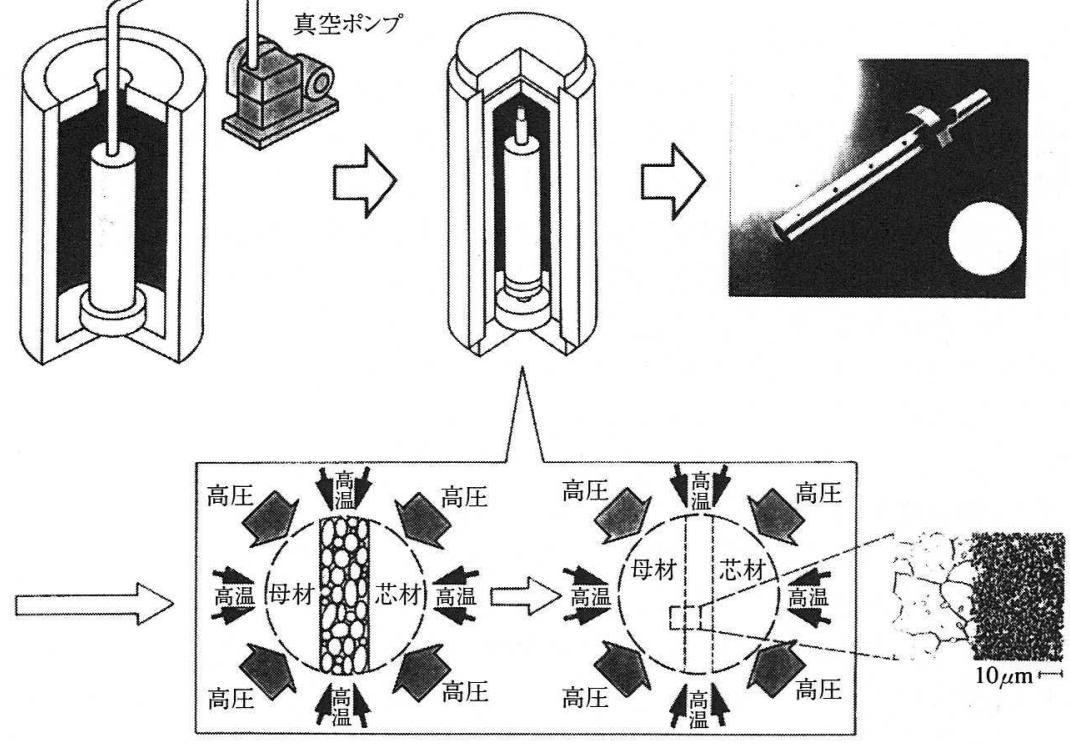

粉末の焼結／母材との拡散接合過程

図 1 HIP 複合シリンダーの製造工程概略

表 1 HIP シリンダー用ライニング合金の特性と適用樹脂

\begin{tabular}{|c|c|c|c|c|}
\hline ライニング合金 & 組 成 & 硬さ (HRC) & 特 性 & 適 用 樹 脂 \\
\hline C 300 & $\mathrm{Ni}$ 基高合金 & $57 \sim 62$ & $\begin{array}{l}\text { 耐 摩 耗 } \\
\text { 耐 食 }\end{array}$ & $\begin{array}{l}\text { 汎用プラスチック（PP, ABS など） } \\
\text { エンプラ（PA, PBT, POM, PCなど） }\end{array}$ \\
\hline C 304 & $\begin{array}{l}\mathrm{Ni} \text { 基高合金 } \\
+ \text { + }\end{array}$ & $63 \sim 68$ & $\begin{array}{l}\text { 高耐摩耗 } \\
\text { 耐 食 }\end{array}$ & $\begin{array}{l}\text { フィラー高含有 ( } 40 \mathrm{wt} \% \text { 以上) エンプラ, } \\
\text { スーパーエンプラ, プラマグ, 金属粉末, } \\
\text { セラミックスなど }\end{array}$ \\
\hline C 330 & $\mathrm{Ni}$ 基高合金 & $58 \sim 62$ & $\begin{array}{l}\text { 耐 摩 耗 } \\
\text { 高 耐 食 }\end{array}$ & $\begin{array}{l}\text { 難燃グレード樹脂, } \\
\text { スーパーエンプラなど }\end{array}$ \\
\hline C 334 & $\begin{array}{l}\mathrm{Ni} \text { 基高合金 } \\
+ \text { + }\end{array}$ & $63 \sim 68$ & $\begin{array}{l}\text { 高耐摩耗 } \\
\text { 高 耐 食 }\end{array}$ & $\begin{array}{l}\text { フィラー高含有 }(40 \mathrm{wt} \% \text { 以上 }) \text { 難燃グレード樹脂, } \\
\text { スーパーエンプラ, プラマグ, 金属粉末, } \\
\text { セラミックスなど }\end{array}$ \\
\hline C 350 & $\mathrm{Ni}$ 基高合金 & $58 \sim 62$ & $\begin{array}{l}\text { 耐 摩 耗 } \\
\text { 超 耐 食 }\end{array}$ & $\begin{array}{l}\text { PPS, 難然グレード樹脂, } \\
\text { スーパーエンプラ }\end{array}$ \\
\hline C 355 & $\begin{array}{l}\mathrm{Ni} \text { 基高合金 } \\
+ \text { セラミックス }\end{array}$ & $63 \sim 68$ & $\begin{array}{l}\text { 高耐摩耗 } \\
\text { 超 耐 食 }\end{array}$ & $\begin{array}{l}\mathrm{PPS}, \\
\text { フィラー高含有（40 wt\%以上）難燃グレード樹脂 }\end{array}$ \\
\hline C 703 & $\mathrm{Ni}$ 基高合金 & $60 \sim 65$ & $\begin{array}{l}\text { 耐 摩 耗 } \\
\text { 超 耐 食 }\end{array}$ & フッ素樹脂 \\
\hline C 900 & $\begin{array}{l}\mathrm{Ni} \text { 基高合金 } \\
+ \text { + }\end{array}$ & $60 \sim 65$ & $\begin{array}{l}\text { 耐 高 圧 } \\
\text { 耐 摩 耗 } \\
\text { 高 耐 食 }\end{array}$ & $\begin{array}{l}2600 \text { 気圧を超える高圧成形に対応可能 } \\
\text { フィラー高含有 ( } 40 \mathrm{wt} \% \text { 以上) 難燃グレード樹脂, } \\
\text { スーパーエンプラ等 }\end{array}$ \\
\hline
\end{tabular}


摩耗が混合した形態を示し,チェックリングとの接触で‘か じり'をともなう複雑な場合もある。

シリンダー内面の損耗傾向を成形樹脂に着目してその形 態で分類すると, 図 2 から図 4 に示す三つの夕イプに大別 される ${ }^{6)}$

$<\mathrm{A}$ タイプ $>$

ガラス繊維などの強化材含有率が 0〜 30 wt \% 程度のエ ンプラ成形では, 樹脂供給部と射出先端側チェックリング との摺動部が初期摩耗する程度で, その他の箇所の摩耗は さほど進まない。

<Bタイプ>

$\mathrm{GF}$ 含有量が $30 \mathrm{wt} \%$ 超える高フィラー樹脂，あるい は $\mathrm{GF}$ に加えて $\mathrm{SiC}$ 等のセラミックス粉末を強化材として 含有する樹脂では, 樹脂供給部と射出先端側チェックリン グとの摺動部の摩耗が比較的速く進む.

$<\mathrm{C}$ タイプ $>$

特殊エンプラのなかで, PPS 樹脂あるいはその他難燃 強化グレード樹脂では, 成形時にフッ素, 塩素あるいは硫 黄系の強腐食性ガスが発生する。 このため, 摩耗に加えて 腐食の影響が強まり, 樹脂供給部と射出先端側チェックリ
ングとの摺動部の摩耗速度が B タイプ樹脂よりさらに速 くなり, かつ計量・圧縮部においても腐食によって内径拡 大が進むのが特徴となっている.

\section{5. 耐 摩 耗 性}

シリンダーの摩耗挙動は, 前述したように(1) 強化材 (GF 等）とライニング合金とのアブレッシブ摩耗, (2)スク リュ・チェックリング等とライニング合金との接触による 摺動摩耗，（3)腐食をともなう腐食摩耗, とシリンダーの 部位により異なる。 その評価には, 種々の方法が用いられ ているが(3) 5), 最も一般的に用いられる評価方法は大越式 摩耗試験で, 主に摺動摩耗特性を評価する方法である. 図 5 に比較試験結果を示す。

HIP 接合法により，均一な組織を有する $\mathrm{Ni}$ 基合金では， 硬質セラミックス添加等の影響はあるが，摩耗特性は概ね 硬さと相関し, 硬さが高い合金ほど摩耗が少ない.アブレッ シブ摩耗の場合は, 硬さが高いほど耐摩耗特性は良くなる ことが知られており, 樹脂供給部の摩耗に対しては, 硬さ の高いライニング合金の方が有利と言える.

一方, 腐食をともなう射出先端側は, 使用樹脂等の腐食

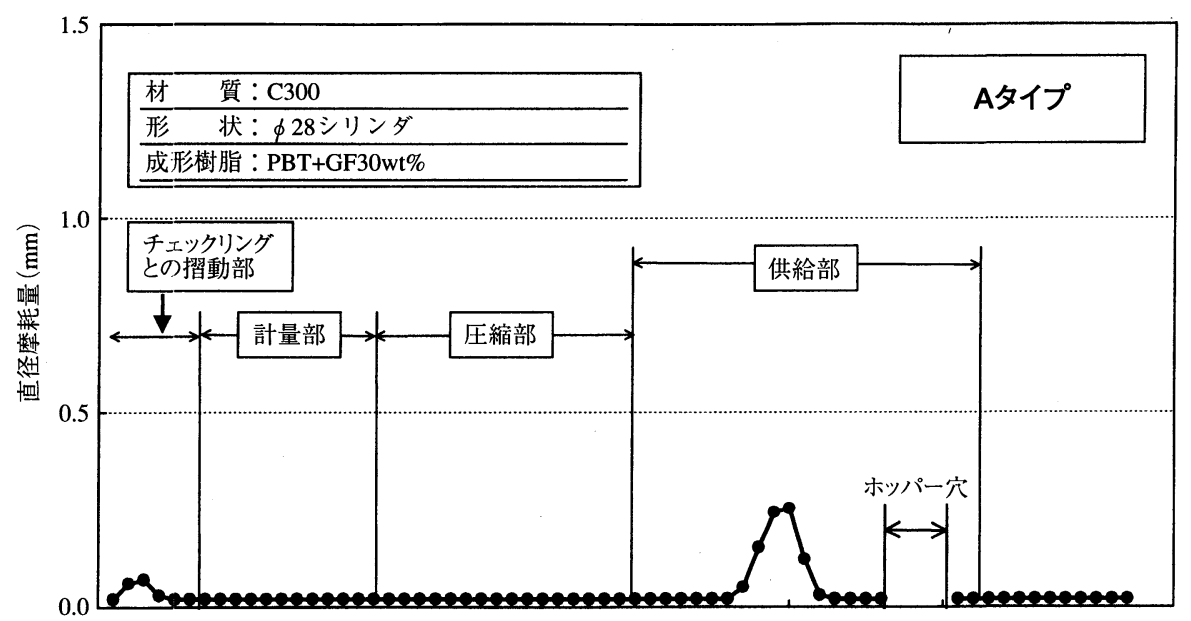

射出側ライニング材端面からの距離

図 2 シリンダー内径摩耗プロファイル（GF 含有量が標準的なエンプラの成形例）



射出側ライニング材端面からの距離

図 3 シリンダー内径摩耗プロファイル（GF 含有量が多いエンプラの成形例） 


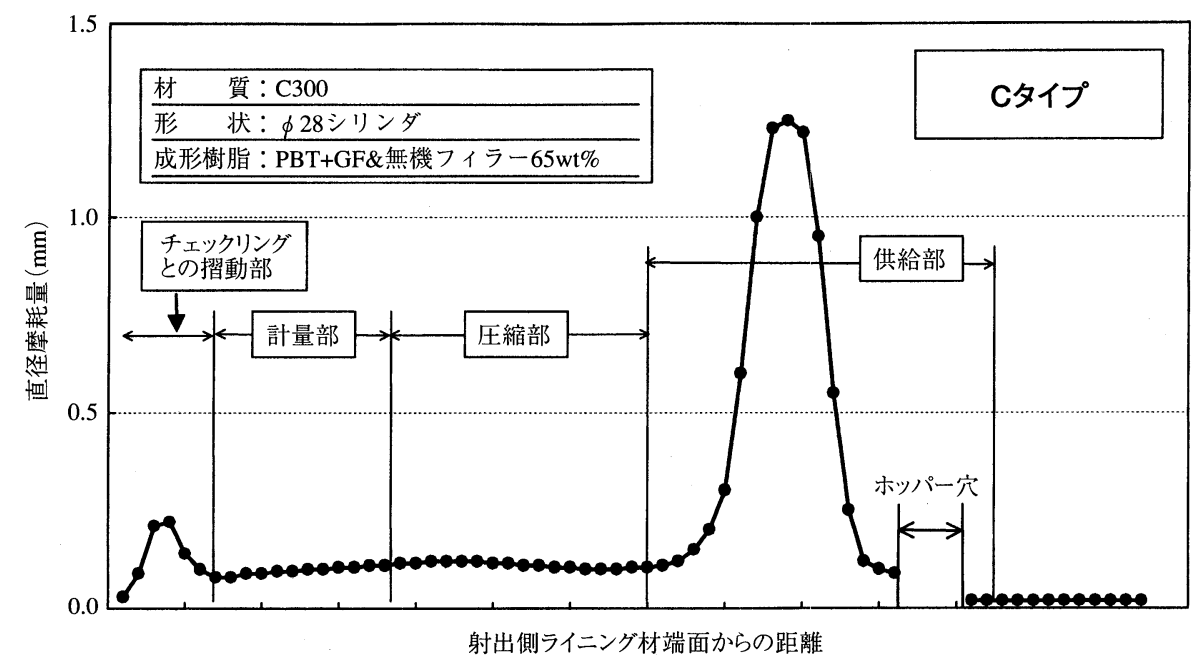

园 4 シリンダー内径摩耗プロファイル（腐食性が強く, GF 含有量が多いエンプラの成形例)

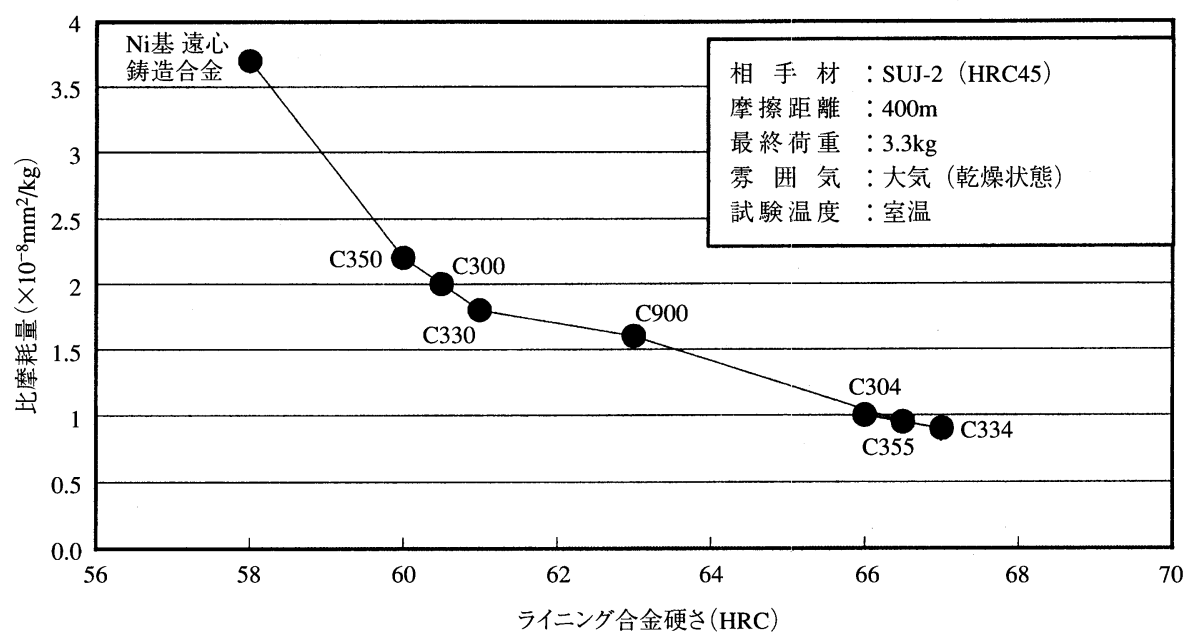

図 5 ライニング合金硬さと比摩耗量(大越摩耗試験による)

ガスの影響も強いため評価が難しく，各種の試験が試みら れている．弊社で実施している腐食・摩耗評価試験方法の 一例を図 6 に示す.

\section{6. 耐 食 性}

\section{1 樹脂からの発生ガス}

成形加工温度と樹脂の分解開始温度が接近している POM,PPS のようなエンプラの場合, 多かれ少なかれ分解 生成物を生じる。また，多くの樹脂は難燃剤や熱安定剤な どの添加物を含有しており，それらから熱分解ガスが発生 する，そのなかで，金属材料の腐食に影響を及ぼすガスは $\mathrm{NO}, \mathrm{NO}_{2}, \mathrm{SO}_{2}, \mathrm{H}_{2} \mathrm{~S}, \mathrm{NH}_{3}, \mathrm{HCN}, \mathrm{HCl}, \mathrm{HF}$ などである. これらのガスは酸素，水分の存在下でライニング合金を腐 食させる7゙. 表 2 に，弊社での各種樹脂の発生ガス測定の 一例を示す。

\section{2 腐食試験結果}

樹脂の熱分解により発生する腐食性ガスを考慮して，最 もライニング合金の腐食に影響すると思われる $\mathrm{HCl}, \mathrm{HF}$ ， $\mathrm{H}_{2} \mathrm{SO}_{4}, \mathrm{H}_{2} \mathrm{~S}$ について, 弊社の代表的な $\mathrm{Ni}$ 基ライニング合 金にて比較試験を実施した例を図 7〜図 10 に示す.

$\mathrm{Ni}$ 基合金の場合, $\mathrm{Ni}$ 自体に多少の耐食性はあるものの,

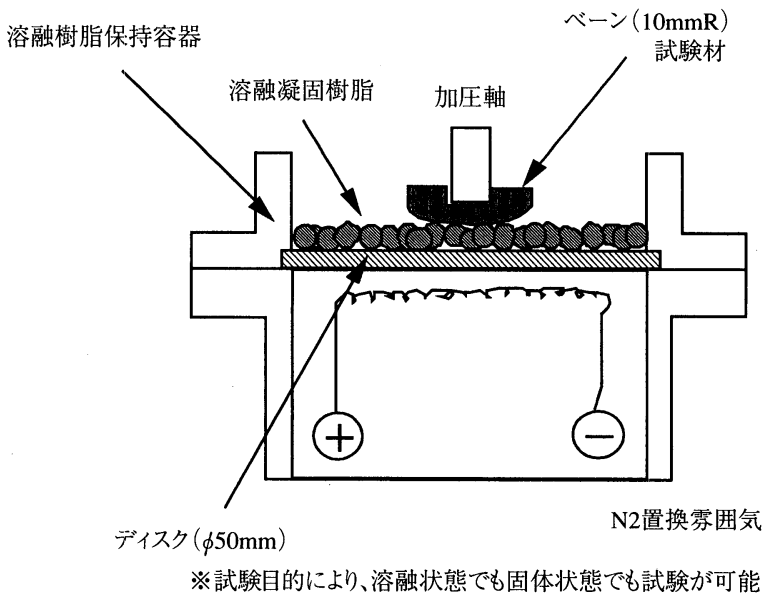

図 6 腐食摩耗試験機

$\mathrm{Cr} ， \mathrm{Mo}$ 等の添加により耐食性は著しく向上する，一般的 に遠心鋳造法などによって得られる合金と比べて, HIP 接 合法はライニング材料の高合金化が可能であるため, 得ら れる合金の耐食性は優れている。また， Cr，Mo 等の合金 元素添加量が多い合金系ほど耐食性に優れる傾向を示す.

なお，高硬度化のために行う硬質セラミックスの添加は 
耐食性にほとんど影響を与えない。

次に, HIP 接合法の $\mathrm{Ni}$ 基と $\mathrm{Co}$ 基ライニング合金の腐 食特性を比較した例を表 3 に示す。この試験は, $\mathrm{Ni}$ 基ラ イニング合金 C 900 とC 900 の NiをCoに置き換え，そ の他成分を同一としたCo 基合金で比較した.

$\mathrm{HCl}$ および $\mathrm{HF}$ における腐食の点で, $\mathrm{Ni}$ 基ベースの方
が優れる傾向を示している，一方， $\mathrm{H}_{2} \mathrm{SO}_{4}$ に対しては，C 900 は $\mathrm{Ni}$ 基遠心鋳造材などに比べて著しく優れているが, Co 基のほうがさらに優れる結果となっている.

このように, $\mathrm{Ni}$ 基と $\mathrm{Co}$ 基では多少異なった特性を示す ことから，用途に応じて使い分けられている.

表 2 樹脂加熱時に発生するガスの分析結果

\begin{tabular}{|c|c|c|c|c|c|c|c|c|}
\hline \multirow{2}{*}{ 樹脂名 } & \multirow{2}{*}{$\begin{array}{c}\text { 加熱温度 } \\
\left({ }^{\circ} \mathrm{C}\right)\end{array}$} & \multicolumn{6}{|c|}{ 発生ガス量（ $\mu \mathrm{g} / \mathrm{g} ）$} & \multirow{2}{*}{ 備考（樹脂のグレード） } \\
\hline & & $\mathrm{F}^{-}$ & $\mathrm{Cl}^{-}$ & $\mathrm{NH}_{3}$ & $\mathrm{H}_{2} \mathrm{~S}$ & $\mathrm{SO}_{2}$ & その他 & \\
\hline ABS & 245 & 25 & 40 & - & $\triangle$ & $\triangle$ & & 超耐熱 \\
\hline PA 46 & 320 & 2 & 1 & 4000 & - & - & $\mathrm{SO}_{4}^{2-}: 1$ & ガラス強化 \\
\hline PA 66 & 250 & - & 11 & 32 & - & - & & ガラス強化 \\
\hline PA 66 & 265 & 48 & 58 & 159 & - & - & & 難燃 \\
\hline PA $6 \mathrm{~T}$ & 330 & - & 130 & 680 & - & - & $\mathrm{SO}_{4}^{2-}: 1, \mathrm{Br}^{-}: 1400, \mathrm{HCl}: 48$ & ガラス強化・難燃 \\
\hline PBT & 250 & 43 & 41 & 2 & - & - & & 強化・難燃 \\
\hline PPS & 330 & 22 & 23 & $\triangle$ & $\triangle$ & $\triangle$ & & 電子・電気用 \\
\hline PPS & 330 & 11 & 30 & 7 & - & $\triangle$ & & 電子・電気用（低反り） \\
\hline PPS & 330 & - & 55 & 5 & - & 9 & $\mathrm{SO}_{4}^{2-}: 28, \mathrm{HCN}: 9$ & 電子・電気用 \\
\hline PSF & 330 & 32 & 138 & - & 171 & - & $\mathrm{SO}_{4}^{2-}: 280, \mathrm{HCl}: 98$ & ガラス強化・絶縁 (低反り) \\
\hline LCP & 320 & 5 & 9 & 1 & - & - & $\mathrm{HCl}: 4$ & 高寸法安定・低異方性 \\
\hline
\end{tabular}

- : ガス発生無し

$\triangle: 0 \sim 5 \mathrm{ppm}$ の微量ガス発生

<ガス分析方法>

1) イオンガスクロマトグラフ : $\mathrm{F}^{-}, \mathrm{Cl}^{-}, \mathrm{Br}^{-}, \mathrm{SO}_{3}, \mathrm{SO}_{4}^{-}, \mathrm{NO}_{2}^{-}, \mathrm{NO}_{3}^{-}, \mathrm{PO}_{4}^{-}$

2) ガスクロマトグラフ : $\mathrm{COS}, \mathrm{H}_{2} \mathrm{~S}, \mathrm{CH}_{3} \mathrm{SH}, \mathrm{CS}_{2}$

3 ) 検知管: $\mathrm{NH}_{3}, \mathrm{HCN}, \mathrm{HCl}, \mathrm{Cl}_{2}, \mathrm{SO}_{2}$

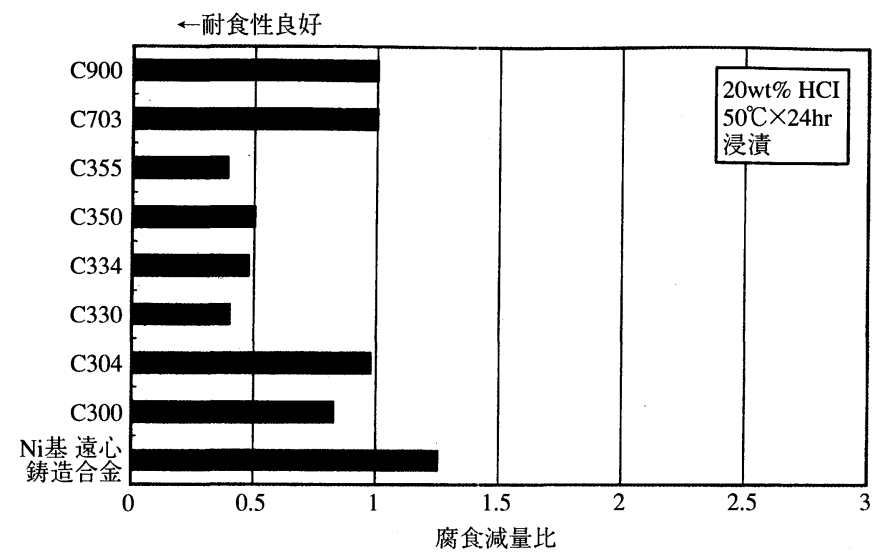

図 7 各ライニング合金の耐食性

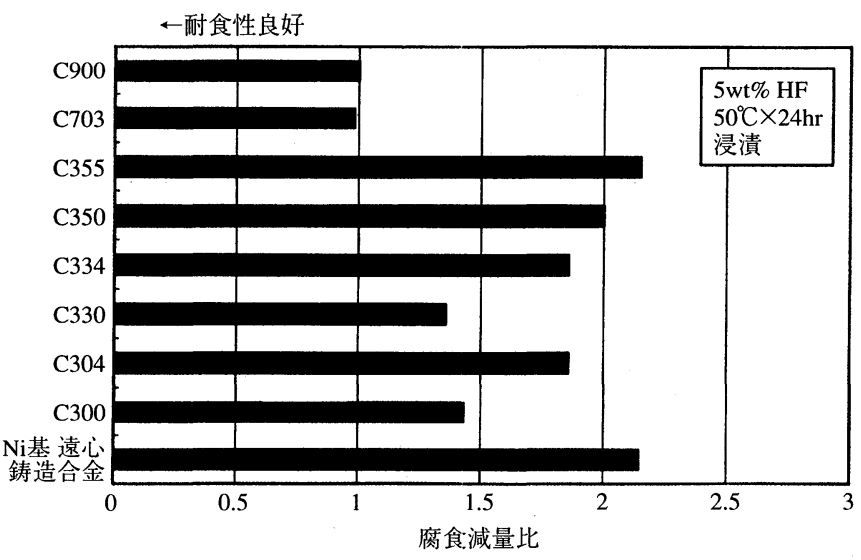

図 8 各ライニング合金の耐食性

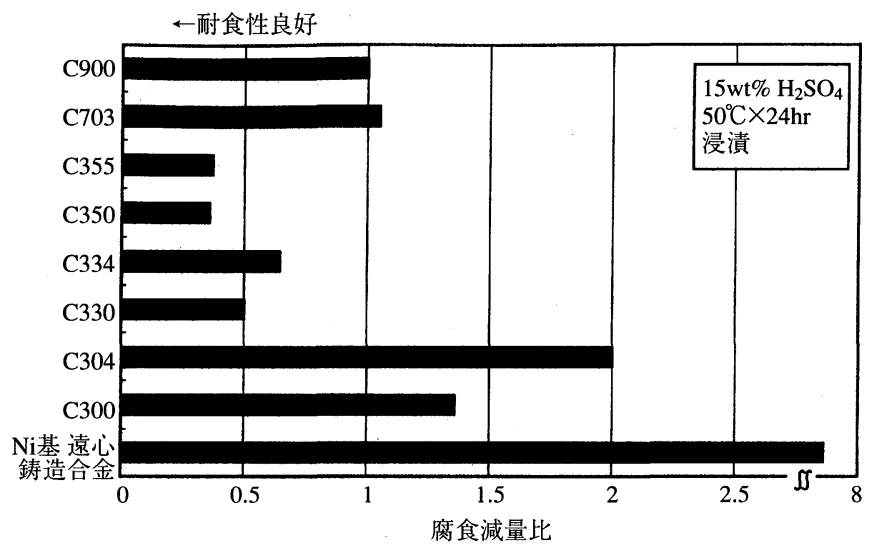

図 9 各ライニング合金の耐食性

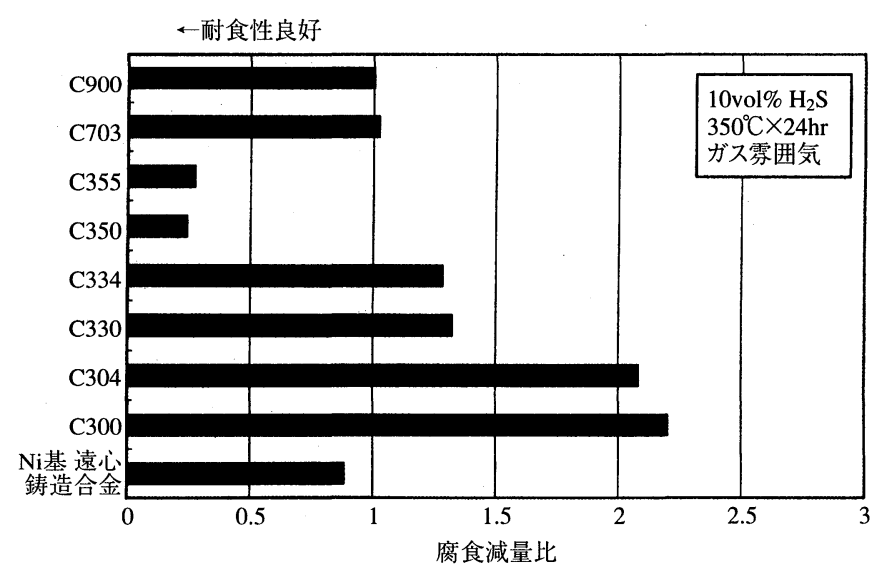

図 10 各ライニング合金の耐食性 
表 $3 \mathrm{Ni}$ 基と $\mathrm{Co}$ 基の耐食性 ${ }^{* *}$ 比較

\begin{tabular}{|c|c|c|c|c|c|}
\hline & $19 \% \mathrm{HCl}$ & $5 \% \mathrm{HF}$ & $15 \% \mathrm{H}_{2} \mathrm{SO}_{4}$ & $7 \% \mathrm{HBr}$ & $6 \% \mathrm{HNO}_{3}$ \\
\hline $\mathrm{Ni}$ 基 (C 900) & 1 & 1 & 9.3 & 1 & 1 \\
\hline Co 基比較材 ${ }^{*}$ & 5.2 & 6.0 & 1 & 1.1 & 1.1 \\
\hline
\end{tabular}

*C 900 の Ni C Coに置換えた試験材

** 腐食隇量が少ない方を基準とした比率（数字が大きいほう が耐食性が悪い)

\section{7 、耐食・耐摩耗を考慮したライニング合金の選定}

\section{1 一般耐食・耐摩耗用ライニング合金}

耐食・耐摩耗性をあまり必要としない汎用プラスチック および強化材を多量に含まないエンプラの成形に対しては, 硬質粒子を含まない C 300 で十分な性能を発揮する.C 300 は（Ni, Cr）の複合ホウ化物および炭化物を $\mathrm{Ni}$ 基合金マ トリタス中に均一に分散した組織を有する。

しかし，GFを $40 \mathrm{wt} \%$ 以上含有したエンプラの成形に 対しては摩耗がより激しくなるため, C 300 に硬質セラ ミックスを MA 法により分散強化させたC 304 の方が望 ましい.

さらに，難燃グレード等を成形する場合，耐食性を考慮 し, C 304 と比べて Cr, Mo 量を増やしたC 334 が適して いる.

\section{2 超耐食・耐摩耗用ライニング合金}

(1) PPS 用

PPSの成形に際しては, 成形時にフッ素, 塩素および アンモニア系ガスに加え, $\mathrm{H}_{2} \mathrm{~S}$ や $\mathrm{SO}_{2}$ などの硫黄系ガスを 発生する特徴があり，ライニング合金は，厳しい腐食環境 に曝される。このため, $\mathrm{H}_{2} \mathrm{~S}$ や $\mathrm{SO}_{2}$ などの硫黄系ガスに対 する耐食性が低いライニング合金の場合，シリンダー寿命 が著しく短くなる（図 4 ；C タイプの損耗が生じる）.

また，PPS 樹脂のほとんどのグレードは GF 等の強化材 が $40 \mathrm{wt} \%$ を超えるため, 高 Cr 配合により硫黄系ガスに 対する耐食性を高めたC 350 に耐摩耗性を考慮して, 特殊 セラミックを添加した C 355 が適している．C 355 は一般 耐食・耐摩耗用の C 300 合金と比較して数倍の耐食性を示 しており，PPS 樹脂成形に対するシリンダー寿命の大幅 な改善が可能となる.

(2) フッ素樹脂用

腐食性の厳しいPFA などのフッ素樹脂の成形には，現 在，超耐食合金であるハステロイCが用いられているが， 硬さが低いためにスクリュとのかじりの発生や充填材が添 加された場合の耐摩耗性の点で問題が生じる場合がある.

この場合，ハステロイCとほほ同等の耐食性を備え， また硬さが HRC 60〜65の範囲とするように，高合金配合 と MA 法によるセラミックの分散強化が施された C 703 が適する.

C 703 の使用例として, GF 3 wt\%含有したPFA 成形 で, 従来のハステロイ系シリンダーに対し, 寿命が約 6 倍
に達する例もあり，フッ素樹脂成形に威力を発揮している.

\section{3 高温高圧成形用}

形状が微細・高精度化した部品や薄肉部品の增加, 樹脂 流動性が恶いエンプラの採用, あるいは成形のハイサイク ル化により,成形条件が高速・高圧化する傾向にある.LCP を始めとするスーパーエンプラの成形などでは，加熱温度 が $400^{\circ} \mathrm{C}$ を超える高温となるとともに, 高速・高圧成形が 必要となっている．このため, シリンダーに対しては従来 にも増して, 耐食性・耐摩耗性はもちろんのこと, 高温で の耐圧強度が要求されるようになってきている。

このような, 最近の高温・高圧化，さらには高速化への 対応には, HIP 接合法により $\mathrm{Cr}, \mathrm{Mo}$ 添加量を増やし, MA 法により硬質な複合ホウ化物を分散させ，高強度かつ高勒 性が得られるC 900 が望ましい。

また近年, 射出圧力が $3200 \mathrm{kgf} / \mathrm{cm}^{2}$ を超え，C 900 シリ ンダーで対応できないような高圧成形に対しては，シリン ダー射出側先端部に高強度スリーブ材を焼嵌めした C 900 焼嵌めシリンダーを使用するケースが增えてきている.

なお, C 900 焼嵌めシリンダーにて, $400^{\circ} \mathrm{C}, 4000 \mathrm{kgf} / \mathrm{cm}^{2}$ と非常に過酷な射出条件にも対応している例もある.

\section{8.おわりに}

以上, HIP 複合シリンダーの腐食・摩耗特性について述 べたが，HIP 複合シリンダーは広範な用途に適用が可能で あり, 従来タイプのバイメタリックシリンダーよりも安定 した寿命延長が図れており，樹脂を問わず成形品質の安 定・向上に役立っている.

さらに，今後，プラスチック材料の高機能化にともなっ て,シリンダーおよびスクリュに対する要求特性はますま す厳しくなり,これに応えるために, 今後とも種々の耐食・ 耐摩耗性材料とその加工法, あるいは表面処理法が実用化 されてくるものと考える.

本稿で紹介した HIP 接合法による複合シリンダーは, 将来的にも高性能化に対応できる発展性の高い技術であり, 特性改善に効力を発揮するものと考える.

\section{参 考 文 献}

1）梅田孝一, 中村茂樹, 草部一郎, 南出俊幸, 森下政夫： 素形材, 5, 7 (1991)

2 ) 梅田孝一, 常陰武良: プラスチックエージ, 38 (9)，153（1992）

3 ）是永逸生, 森 孝志, 沖津俊夫, 福沢 宏, 天野正則, 山下栄一：日立金属技報，6，95（1990）

4 ) 肥田 修: プラスチック成形技術, 8(12), 29 (1991).

5 ）中野和則：プラスチック成形技術，8(12)，23 (1991).

6 ）南出俊幸, 西川正寿: プラスチック成形技術, 8 (12), 35 (1991).

7 ) 黒江龍朗，林 隆一：プラスチックエージ, 38 (9), 130 (1992) 